\title{
Acts of Corporations as the Main Factor in the Lapse of the Right of Participation in Corporations
}

\author{
Saglar S. Ashtaeva \\ Kalmyk State University, Elista, Russia \\ Tatyana V. Deriugina \\ Volgograd Institute of Humanities, Volgograd, Russia \\ Altana A. Noyanova \\ Kalmyk State University, Elista, Russia \\ Emilia K. Hasikova \\ Kalmyk State University, Elista, Russia \\ Lydia D Burinova \\ Kalmyk State University, Elista, Russia \\ Email: Eldirect@mail.ru,ashtaeva.s@ramvler.ru
}

\section{Doi:10.5901/mjss.2015.v6n3p169}

\section{Abstract}

The article is devoted to acts of corporations as the main factor in the lapse of the right of participation in corporations. In recent years corporate relations in general were the object of scrutiny. The main discussion was expanded in the field of explanations of their nature and place in the system of civil law. The priority was the concept of special and not contractual nature of corporate relations. The result of developed dispute was large-scale changes in the legislation of the Russian Federation on legal entities. The changes affected not only the Civil code of the Russian Federation (hereinafter - the CC), but the Federal law of 08.02.1998 No. 14-FL "On limited liability companies", the Federal law dated 26.12.1995 No. 208-FL "On joint stock companies". The lapse of the right of participation is associated primarily with the disappearance of one of the parties of the membership relationship. It is either a liquidation of the corporation, the output of member of the corporation, or conclusion of disposing civil transactions. Liquidation is considered as a corporate procedure, resulting in the termination of a legal entity. Liquidation is considered as a corporate procedure, resulting in the lapse of a legal entity. The output of member of the economic society is carried out on the basis of his act. Thus, such an act would be in itself a ground for lapse of the participation rights as since its implementation the legal status of the participant is lapsed. Participation right is lapsed by one partner and begins with another. For a business entity any effect does not occur, because the identity of a particular participant does not matter, there are no changrs in the structure of the corporation. Only the subject is changing in the membership relationship.

Keywords: participation in the corporation, the corporation, the right to participate, a business company.

\section{Introduction}

Any business company exercises the rights and acquires responsibilities through its bodies. Acts of bodies of the legal entity are legal facts (Bevzenko, R.S. Theory of legal facts, 2007.). There is generally accepted scientific classification of bodies of a legal entity:

a) individual;

b) collegial.

The first group is the individual executive body. The collegial include: the general meeting of members of the corporation, the board of directors (supervisory council), the collegial executive body. 
In our opinion the most controversial category of corporate law are the acts of the collegial executive bodies. It is written very much about the decisions of general meetings in foreign and domestic literature. For example, R. S. Bevzenko identifies the following approaches to the legal nature of decisions of the general meeting of members of corporations:

a) the theory of normative local act;

b) the theory of dealing;

c) the theoru of special legal fact;

d) the theory of non-normative legal act (Berle, Adolf A., 1991; Berle F.F., 1991 and civil Code of Russia, http://base.consultant.ru/cons/cgi/online.cgi?base=LAW;n=156206;req=doc).

Normative theory ranks the solutions to sources of objective right. One of the varieties of normative theory was the theory of socio-legal act (Vilkin, S. S., 2009; and Cahn, Andreas, 2010), in which the decision was perceived as a normative act for persons involved in the corporation.

The following approach is the most common and significant in the Russian scientific literature, it is the transaction theory of decisions of the general meeting of the members of the corporation. In favor of the transaction theory of decisions of the general meeting of participants with arguments indicates, that:

a) the solution is directed will of the legal person, which has a legal character, being a rule of conduct, defined by individuals vested power in body of the legal entity (Rubenko, G. L., 2015);

b) the solution entails legal consequences, which aims such will, such as creating obligations for the participants of the legal entity and its bodies, changes in the organizational unit of a legal entity, the occurrence of contractual rights requirements, authorizing of any action or other consequences. (Rubenko, G.L., 2015).

Furthermore, in his researches Stepanov D. I. in particular notes that the decision of the general meeting of participants of the corporation has initially lawful character and definitely is a legal fact, because that creates, modifies and terminates civil matters. (Kuzmin, A.l., 2014; Clark, Robert C., 1986; and Orts, E., 1992).

The priority was the concept of special and not contractural nature of corporate relations (Drury, R., 2007; Parkinson, J., 1993.; and Robert, A.G., 1995). The result of permitted dispute became large-scale changes in the legislation of the Russian Federation on legal entities. The changes affected not only the Civil code of the Russian Federation (hereinafter - the CC), but also the Federal law of 08.02.1998 No. 14-FL "On limited liability companies" (Civil code of the Russian Federation (hereinafter - the CC) and Federal law from 08.02.1998 No. 14-FL, http://base.consultant.ru/cons/cgi/online.cgi?base=LAW;n=156206;req=doc), the Federal law dated 26.12.1995 No. 208FZ "On joint stock companies" (Civil code of the Russian Federation, part two from 26.01.1996 No. 14-FL, http://www.consultant.ru/popular/gkrf2/).

\section{Materials and Methods}

The decision of the general meeting of participants is recognized the special legal fact, which does not apply to transactions. The total resolution of the meeting of participants of the economic entity, with the purposes of the acquisition of property of a legal fact, should go through the procedure stipulated by the law that provides the decision in accordance with the competence of the authority. These factors contribute to the interests of the corporation and its members in particular, ensure the will of the voting persons and fixation of this desire.

The will of the participants is one-sided binding transactions that do not have a counter character. The decision of the general meeting, usually do not consider an act of will, because there is no formation of any joint will. In the basis of decisions of the General Assembly lies volitional activity, as the will manifests itself in the voting procedure and its defect should be evaluated only in the study of voting. Therefore, the acts of corporations include acts of bodies of legal entities, aimed at the movement of internal relations (Ashtaeva, S. S., 2013; Cohen, M. S., 2008; and Kraakman, Renier, 2009).

It should be noted that the classification, considering from the point of view of civil law, depends on which the body of the legal entity made the decision:

a) collegial;

b) individual.

So, the acts of the individual executive body, in the framework of corporate relations, must be qualified as legal actions. And acts of collegial bodies can be classified as collegial volitional acts, a special group of legal facts. A process procedure of their adoption, the grounds of invalidity and legal consequences that they entail unite these acts. The procedure for the lapse of the right of participation may occur when:

a) liquidation of the company;

b) exit from company; 
c) exclusion of partner.

In accordance with the Art. $62 \mathrm{CC}$ the decision on liquidation should contain not only the decision to dissolve the corporation (Gabov, A.V., 2011), but must also be specified the time and manner of carrying out this enterprise procedures. After the decision on liquidation the corporation ceases to exist (Gabov, A.V., 2011), as a consequence the corporate legal relations break up and all rights of participation in society is redeemed. To the legal forms of liquidation of the legal entity can be attributed the circumstances:

a) grounds for liquidation (Gabov, A.V., 2011). That is, those legal facts, with which the legislation relates the beginning of the liquidation procedure;

b) the order of liquidation. That is, the set of legal facts necessary for any legal purpose of liquidation (laose of a legal entity);

c) consequences liquidation. An important consequence is the lapse of a legal entity. An important feature of the solution is its real, enforceable nature.

Information letter of the Presidium of the Supreme Arbitration Court of the Russian Federation of 13.01.2000 No. 50 (Arbitration procedural code of the Russian Federation dated 24.07.2002 No. 95-FL, http://www.consultant.rul popular/apkrf/) when resolving disputes related to the liquidation of commercial organizations, proposes to apply the rule, when the decision on voluntary liquidation of a legal entity does not exclude the possibility of recourse to the court for its compulsory liquidation, if the above solution fails and there are grounds provided for $n$. 2 Art. 61 of the CC of RF.

Gabov A. V. in his works believes that inane decision on liquidation cannot be without the appointment of a liquidation Commission, the detailed definition of the order of liquidation and its specific term (Ashtaeva, S.S., 2013). For its purpose the decision on reorganization of the company and the decision on liquidation is similar in many points. For example, the liquidation decision also establishes the procedure, rules of conduct, the liquidation procedure, however, is not grounds for lapse of the participation rights. However, in terms of violations of established by the corporation and the law liquidation procedure shall entail the invalidity of the entire liquidation.

The decision of the general meeting of commercial companies runs, and most importantly regulates the legal structure of the liquidation of the company. At the same time, the separate corporate acts of the parties or of the individual executive body do not have any independent value. It happens because this procedure affects the rights of third parties, as well as to the participation rights of all members of the corporation.

In connection with the disappearance of one of the parties the membership of legal relations terminates and as a consequence cease participation rights.

The main feature of the procedure of lapse of the right of participation is the widespread use of acts of members of corporations. So, in joint stock companies often used the right of the participant (shareholder) on redemption of shares (Glushetski, A.A., 2013., http://base.garant.ru/70109900/1/). For example, in accordance with Art. 75 of the Law on joint stock companies the right of a shareholder to require the compulsory redemption of his shares by the company is established. The redemption of shares by a person who has acquired more than $95 \%$ of the shares, at the request of other shareholders regulates Art. 84.7. Article 84.8 of the Law on corporations establishe reverse obligation of the shareholders to sell their shares upon request of the person who has acquired more than $95 \%$ of the shares in the authorized capital of the company. In addition there are the shareholders ' request for redemption of shares - in this case, there are also grounds for lapse of the participation rights (Glushetski, A.A., 2013., http://base.garant.ru/70109900/1/). In each of these cases happens the lapse of the participation rights in the society and these sample requirements, as stated above, are unilaterally binding transactions. There is no need for any other transactions for the ensuing consequences. It can be stated that the corporations the right of participation may be terminated unilaterally. The position of some authors runs that this requirement constitutes an offer to the buyer, and is not true.

The offer implies a further conclusion of a civil contract. At purchase of shares there is no agreement, the obligation arises by virtue of the application requirements, conditions are determined in the order prescribed by law and are objective (Glushetski, A.A., 2013.). From this it can be concluded that in this case tere is no existence of a civil contract (Vilkin, S.S., 2009, http://base.garant.ru/70109900/1/).

The coercive and unilateral nature of corporate relations appears, after the lapse of membership relations at the company's property duty on paymentof the value of the shares occurs.

Identical is the situation with the output member of the LLC (limited liability Company: the Federal law from 08.02.1998 No. 14-FL, http://www.consultant.ru/popular/o0o/). This transaction, in itself, is ground for lapse of the right of participation. Under part 7 of article 23 of the Law on LLC the share proceeds to the company from the date of receipt by the company of the participant's application to withdraw from the society or the requirements of this share repurchase.

And in this case, this situation cannot speak about signing any civil contract (The Concept of development of civil legislation of the Russian Federation, appr. by the decision of the Council under the President of RF 
http://base.consultant.ru/cons/cgi/online.cgi?base=LAW;n=95075;req=doc).

It can be stated that in the conditions of lapse of the right of participation unilaterally require the existence of regulatory bodies and legal relation prerequisites.

That is, the appropriate legal relations related to participants ' votes on certain issues are necessary, when the direction of requirements connected with making certain decisions. Regulatory prerequisites are the provisions of the legislation of the Russian Federation, the company Charter, decisions of the General shareholders meeting, which will regulate the ability and the exercise of the powers of the output. In law prerequisites must be included General civil legal personality.

Thus, taking into account both the presence of conditions for lapse of the right of participation and expression in accordance with the legislation of the Russian Federation there is a right to lapse the participation rights. It should be noted that the will must be made on the form prescribed by the legislation of the Russian Federation. The ability of a party to unilaterally lapse membership in the society confirms the importance of the sign of the membership relationship. The emergence of a contractual relationship arises from the moment of lapse of the relationship, and the termination of the right of participation (Kuzmin, A.I., 2014).

The multiplicity of acts of application of corporate companies, aimed at the lapse of the right of participation in societies that create a protective legal framework, providing opportunities for participants to leave the corporation on their own. In contrast, the acquisition of the right of participation in the corporation and its members are virtually non-existent due to the fact that joining the ranks of the members of the corporation may be made only as a result of a civil law transaction, either as a result of changes in the structure of society.

The emergence and lapse of the right to participate in corporate companies is always associated with the origination and lapse of membership, the membership relationship. Share or shares does not pass to the company and back to the participants (Kuzmin, A. I., 2014). They arise at one party membership relationship and are lapsed in connection with its disappearance. The reason for accrual of the right of partisipation is the fact of establishment of the corporation, or its contribution to the authorized capital of the corporation. Ground for lapse of the right of participation is the termination of the corporation, the participant unilaterally. (Berle, F.F. and Means G.C., 1991)

Changing participation rights can be quantitative and qualitative. Quantitative changes associated with changes in the ratio of the company shares, and quality due to volume changes in rights participation rights or the manner of their implementation.

The basis for quantitative changes is the investment in the assets of the corporation, or the acquisition of shares by the member of the corporation, if such actions involve a change in the ratio of shares in the company.

Qualitative changes associated with the existence of the new edition of the Charter of the Corporation or its internal documents. Qualitative changes associates with the existence of the new edition of the Charter of the corporation or its internal documents.

Collective volitions are not legal basis for the emergence, change and lapse of participation rights. Such acts are installing only the rules of procedure, which may occur in the movement of the participation rights are preconditions of such motion. (Kuzmin, A.I., 2014).

The acts of a member of the corporation are not the basis of the origin and changes of the right of participation, however, may constitute ground for lapse of the participation rights. The lapse of the right of participation is possible in the unilateral action of the party the corporation aimed at the exit of the corporation.

\section{Conclusion}

At the conclusion of accurateley civil transactions there is a change in the membership of the legal side of the member of corporation, then as a meaningful relationship does not change. As the result of this transaction, the party always ends the right to participate and it occurs in another subject (side of deal). For corporations, this action has no legal significance because it does not change its structure, the share capital remains fully paid. (Berle, F.F. and Means G.C., 1991).

\section{Acknowledgement}

This article is prepared within the project of the government assignment of the Ministry of education and science "The Legal status of business entities: current status of the Institute and prospects of development" (KlamykSU, project code № 589) 


\section{References}

The arbitration procedural code of the Russian Federation dated 24.07.2002 No. 95-FL // Russ. newsp. - 2002 . - July 27. http://www.consultant.ru/popular/apkrf/.

Civil code of the Russian Federation (hereinafter - the CC), and the Federal law of 08.02.1998 No. 14-FL, http://base.consultant.ru/cons/ cgi/online.cgi?base=LAW;n=156206;req=doc.

On joint stock companies Federal law dated 26.12.1995 No. 208-FL // Russ. newsp. 1995.

About societies with limited liability: the Federal law from 08.02.1998 No. 14-FL // ON the Russian Federation. - 1998. No.7. Art. 785.

The concept of development of civil legislation of the Russian Federation, accept. the decision of the Council under the RF President on codification and improvement of civil legislation from 07.10.2009 // the SCC of the Russian Federation. No.11.

Bevzenko, R.S., 2007. Theory of legal facts // Civil law: actual problems of theory and practice / edited V. A. Belov. M :Yurat-Izdat. 367 pp.

Wilkin, S.S., 2009. Civil-legal nature of the volitional acts of collective bodies of the legal entity: dis...Cand Sc. Law, M.

Gabov, A.V., 2011. Liquidation of legal entities: the history of the development of the Institute in the Russian law, contemporary issues and perspectives. M: The Statute. 122 pp.

Glushetski, A.A., 2013. The repurchase of shares by the shareholders: controversial moments // ec. and right. 2013. No. 4. 31 pp. http://base.garant.ru/70109900/1/.

Kuzmin, A.I., 2014. The emergence, change and lapse of the right of participation in business associations on the basis of acts of the corporation and its participants: dis....Cand. Sc. Law.

Rubeco, G.L., 2015. Reform of the legislation on legal entities in the context of the overall modernization of the Russian civil legislation of the // actual problems of private and public law. Elista: Publishing house of KalmSU, WAD "RPEP Dzhangar".

Ashtaeva, S.S., 2013. State corporation in Russia, their formation and role in economic development // the Right and the state: theory and practice. No. 12. $140 \mathrm{pp}$.

Berle, Adolf A., 1991 The modern corporation and private property / Adolf A. Berle, Gardiner C. Means. - Reprint ed. - Transaction Publishers.

Berle, F.F. and Means G.C., 1991. The modern corporation and property / With a New Introduction by Murray L. Weidenbaum and Mark Jensen. Transaction Publishers New Brunswick (U.S.A.) and London (U.K.).

Cahn, Andreas., 2010. Comparative company law: text and cases on the laws governing corporations in Germany, the UK, and the USA I Andreas Cahn, David C. Donald. - Cambridge University Press.

Clark, Robert C., 1986. Corporate law / C. Clark Robert. — A A Balkema.

Cohen, M.S., 2008. Grounds for Disregarding the Corporate Entity and Piercing'the Corporate Veil // American Jurisprudence Proof of Facts. 3d Database. Updated January 2008. // Westlaw.

Drury, R., 2007. Jurisdiction over foreign corporations: a survey // Lloyd's Maritime and' Commercial Law Quarterly. Part 4.

Kraakman, Renier, 2009. The anatomy of corporate law: a comparative and functional approach / Renier Kraakman. 2 ed. USA: Oxford University Press.

Orts, E., 1992. Beyond Shareholders: Interpreting Corporate Constituency Statutes. 61 Geo. Wash L. Rev.

Parkinson, J., 1993. Corporate Power and Responsibility. Oxford.

Robert, A.G., 1995. Monks and Nell Minow, Corporate Governance // Blackwell Publishers Inc. Maiden. Massachusetts. 